this may dilute the equilibrated mixture of carbon-12 and carbon-14. Warnings like this do not, of course, invalidate the carbon-14 method of study ; but they do impress upon us that we must be slow in accepting as infallible new methods of study until all the possible factors and circumstances bearing upon them have been considered and studied.

\section{Forestry and Conservation in South Africa}

In a recent issue of the Journal of the South African Forestry Association (Pretoria; No. 20, April 1951), under "Editorial Notes and Comments", there is a strong note on forestry and conservation which is equally applicable to a good many other parts of the world. The note points out that the South African forester and his activities are often condemned by his compatriots when in other countries they would be regarded as constructive and conservational. At one time or another, the forester has been accused of causing erosion, desiccation, destruction of the indigenous vegetation, of championing the exotic against the indigenous tree, of despoiling the beauty of the countryside with artificial plantations (some of these complaints have been heard in Great Britain) and so forth. The note continues to the effect that, so far as South Africa is concerned, if these accusations could be substantiated they would apply with a far greater force to the agricultural operations carried out in that somewhat arid land during the past half-century ; this view is supported and expressed by the editor of the Journal of the Botanical Society of South Africa (Part 35; 1949) in the following words. "The effect of afforestation upon water supplies has been ably analysed and discussed by Dr. C. L. Wicht (Department of Forestry Bulletin No. $33 ; 1949$ ). Much is still uncertain and awaits the results of experiments which are in progress. But it is clear, incidentally, that the relative importance of this subject has been much exaggerated when compared with the obvious flagrant and destructive results of much current agricultural and pastoral practice over great areas in the Union. The work of the Forest Department is mainly constructive and conservational ; our farming methods are largely exploitational."

\section{Artificial Insemination of Birds}

THE first Supplement Number of The Onderstepoort Journal of Veterinary Reserrch (1951. Gov. Printer, Pretoria. 5s., overseas postage $1 s$.) is devoted to a valuable paper, 212 pages long, by G. C. van Drimmelen, on artificial insemination of birds by the intraperitoneal route. The paper discusses the historical background of this subject, its literature, and the author's own extensive work. There are three appendixes, one on the intraperitoneal method of insemination, one on the fowl cocks and the semen samples used, and the third on the post-mortem examination of the genitalia of hens. The biblio. graphy, $11 \frac{1}{2}$ pages long, will be useful to all workers on this sulject.

\section{University of Leeds}

IT has been announced from the University of Leeds that the title of emeritus professor has been conferred upon Prof. R. Whiddington on his retirement from the Cavendish chair of physics. Dr. J. G. Wilson, senicr lecturer in physics in the University of Manchester, has been appointed to a chair of physics at Leeds as from June 24, 1952.
The following lecturers (in the subjects and/or departments as shown) have been appointed : K. L. Holmes (anatomy), G. A. Mogey (pharmacology), K. G. Towers (veterinary officer and lecturer in veterinary hygiene in the Department of Agriculture), Dr. F. K. Sutcliffe (research lecturer in the Department of Colour Chemistry and Dyeing), and Dr. R. Reed (Department of Leather Industries).

\section{The Night Sky in November}

Full moon occurs on Nov. 13d. 15h. 52m., U.T., and new moon on Nov. $29 \mathrm{~d} .01 \mathrm{~h} .00 \mathrm{~m}$. The following conjunctions with the moon take place: Nov. 10d., 06h., Jupiter $4^{\circ}$ S. ; Nov. 24d. 1lh., Mars $4^{\circ}$ N.; Nov. 25d. 10h., Saturn $6^{\circ}$ N. ; Nov. 25d. 18h.,.Venus $6^{\circ}$ N.; Nov. 30 d. 14h., Mercury $2^{\circ}$ N. In addition to these conjunctions with the moon, Venus is in conjunction with Saturn on Nov. 2ld. 10h., Venus being $0 \cdot 6^{\circ} \mathrm{S}$. Mercury sets too soon after the sun during the greater portion of the month for favourable observation; the planet attains its greatest elongation east on November 28, and on November 30 sets nearly an hour after sunset, when it can be seen in the western sky for a short time. Venus, a morning star, rises at about $2 \mathrm{~h} .40 \mathrm{~m}$. up to the middle of the month, and at $3 \mathrm{~h} .20 \mathrm{~m}$. at the end of the month, with stellar magnitude -4 and the visible portion of the illuminated disk varying between 0.42 and 0.58 . Mars is a morning star, stellar magnitude $1 \cdot 7$, rising a little before $2 \mathrm{~h}$. throughout November. Jupiter is visible throughout the night, setting at $3 \mathrm{~h} .45 \mathrm{~m}$. on November 1 and at $1 \mathrm{~h} .45 \mathrm{~m}$. on November 30 , stellar magnitude $-2 \cdot 3$; the planet is stationary on November 30 , after which it has an eastward movement in the constellation Pisces. Saturn is a morning star, rising at $4 \mathrm{~h} .10 \mathrm{~m} ., 3 \mathrm{~h} .20 \mathrm{~m}$. , and $2 \mathrm{~h} .30 \mathrm{~m}$. on November 1 , I5 and 30 , respectively, and is easily recognized a little south of $\gamma \mathrm{V}$ irginis in the early part of the month. Only one star brighter than magnitude 6 is occulted in November; on Nov. 10d. 17h. $40.6 \mathrm{~m}$., $\delta$ Piscium disappears (observable at Greenwich). The Leonid meteors, towards the middle of the month, which have been very feeble for many years, will be difficult to observe owing to moonlight.

\section{Announcements}

H.R.H. THE DUKE OF EdINBURGH has been elected an honorary fellow of the Institute of Navigation.

THE Royal Society of New Zealand has awarded the T. K. Sidey Medal and Prize for 1951 to Prof. V.A. Bailey, professor of experimental physics in the University of Sydney, for "research in Radiation as bearing on Human Welfare". This Award is the most important made by the Royal Society of New Zealand by virtue of its international character. It was established to commemorate the passing by the New Zealand Parliament of the Summer Timo Act, 1927 , and was raised by shilling subscriptions, thus making possible a tribute by all to the value of the measure to human welfare.

THE following appointments have been made in the University of Sheffield: Dr. T. H. Barton, lecturer in electrical engineering; Drs. W. H. Evans, H. C. Grimshaw, E. M. Guenault, W. C. F. Shepherd and F. V. 'Tideswell, to be honorary lecturers in mining. The John stokes Research Fellowship has been awarded to Mr. H. L. Kornberg, who will work in the Department of Biochemistry; a Knoop Research Fellowship in Economics has been awarded to Mr. D. C. Corner. 